\title{
MORPHOLOGIC AND MORPHOMETRIC EVALUATION OF PANCREATIC ISLETS IN CHRONIC CHAGAS' DISEASE
}

\author{
João Carlos Saldanha, Vitorino Modesto dos Santos, Marlene Antônia dos Reis, \\ Daniel Ferreira da Cunha and Vicente de Paula Antunes Teixeira
}

SALDANHA JC et al. - Morphologic and morphometric evaluation of pancreatic islets in chronic Chagas' disease. Rev. Hosp. Clín. Fac. Med. S. Paulo 56(5):131-138, 2001.

Purpose: Hyperglycemia and abnormal glucose tolerance tests observed in some patients with chronic Chagas' disease suggest the possibility of morphological changes in pancreatic islets and/or denervation. The purpose of this study was to describe the morphology and morphometry of pancreatic islets in chronic Chagas' disease.

Methods: Morphologic and computerized morphometric studies were performed in fragments of the head, body, and tail regions of the pancreas obtained at necropsies of 8 normal controls and 17 patients with chronic Chagas' disease: 8 with the digestive form (Megas) and 9 with the congestive heart failure form.

Results: The Megas group had a larger $(\mathrm{p}<0.05)$ pancreatic islet area in the tail of the pancreas $\left(10649.3 \pm 4408.8 \mu \mathrm{m}^{2}\right)$ than the normal control $\left(9481.8 \pm 3242.4 \mu \mathrm{m}^{2}\right)$ and congestive heart failure $\left(9475.1 \pm 2104.9 \mu \mathrm{m}^{2}\right)$ groups; likewise, the density of the pancreatic islets (PI) was greater ( $1.2 \pm 0.7$ vs. $0.9 \pm 0.6$ vs. $1.9 \pm 1.0 \mathrm{PI} / \mathrm{mm}^{2}$, respectively). In the tail region of the pancreas of patients with the Megas form, there was a significant and positive correlation $(\mathrm{r}=+0.73)$ between the area and density of pancreatic islets. Discrete fibrosis and leukocytic infiltrates were found in pancreatic ganglia and pancreatic islets of the patients with Chagas' disease. Trypanosoma cruzi nests were not observed in the examined sections. Individuals with the Megas form of Chagas' disease showed increased area and density of pancreatic islets in the tail of the pancreas.

Conclusion: The observed morphometric and morphologic alterations are consistent with functional changes in the pancreas, including glycemia and insulin disturbances.

DESCRIPTORS: Chagas' disease. Morphometry. Pancreatic islets. Pancreas.

Well-known clinical manifestations of chronic Chagas' disease include cardiac, esophageal, and colonic symptoms, which are often associated with visceral inflammation and parasympathetic denervation ${ }^{1}$. Some studies also suggest a more widespread parasympathetic denervation in chronic Chagas' disease. Manifestations of autonomic nervous system imbalance could include abnormalities in gallbladder function and higher frequency of cholelithiasis $^{2}$, abnormalities in iris shape $^{3}$, and increased frequency of headache ${ }^{4}$.

Altered glucose and insulin responses after oral glucose tolerance tests have been described in chronic Chagas' disease and could be due to local parasitic action, $\beta$-cell involvement in chronic inflammation, or partial denervation of pancreatic islets

From the Department of Pathology, Faculty of Medicine, Triângulo Mineiro.
$(\mathrm{PI})^{5-8}$. Nevertheless, studies describing the morphology of the pancreas in Chagas' disease patients are scanty. Vieira \& Hadler reported a variable grade of fibrosis in the pancreas, which they named "pancreatic cirrhosis". In a pilot study, our group described increased PI size in necropsied patients with chronic Chagas' disease ${ }^{10}$. Rocha et al. also observed significant neuronal depopulation in the pancreas of 12 chronic Chagas patients, when compared to 14 normal controls ${ }^{5}$. Santos et 
al. described intrapancreatic neuronal depopulation and perineural leucocyte infiltrate in the pancreas of 6 women with chronic Chagas' disease ${ }^{6}$.

Because of the interrelationships of PI and the intestinal tube (substrate, nerves, and peptidergic routes), and because patients with the digestive form of chronic Chagas' disease have a tendency to show higher degrees of parasympathetic nervous system denervation and altered glucose and insulin curves after oral glucose tests ${ }^{7,11}$, we hypothesized that patients with the Megas form of Chagas' disease would have significant morphologic and morphometric differences in the PI, when compared to patients with the congestive heart failure (CHF), form or to normal controls.

The purpose of this study was to describe the morphology and morphometry of PI in individuals with chronic Chagas' disease, and to compare the area and density of the PI of patients with the Megas and CHF forms of Chagas' disease to a normal control group.

\section{MATERIALS AND METHODS}

This study was conducted in accordance with the Helsinki Declaration Ethics guidelines and approved by the Research Ethics Committee of the Triângulo Mineiro Medical School. Seventeen necropsied patients with chronic Chagas' disease were studied; 8 of them had the Megas (megaesophagus and/or megacolon) form, and 9 died from CHF associated with cardiomyopathy. The diagnosis of Chagas' disease was based upon positive $T$. cruzi serologic reactions (immunofluorescence, complement fixation, and hemagglutination) performed on the pericardial fluid obtained at necropsies $^{12}$. Eight normal individuals, paired in relation to age, gender, and color, were studied as a control group. Nutri- tional status was assessed by the body mass index (BMI) ${ }^{13,14}$, based on both body weight and height registered at necropsy $\left(\mathrm{BMI}=\mathrm{wt}(\mathrm{kg}) / \mathrm{ht}^{2}\left(\mathrm{~m}^{2}\right)\right.$. The malnourished group consisted of individuals with $\mathrm{BMI}<18.5 \mathrm{~kg} / \mathrm{m}^{2}$. Cases with chronic pancreatitis, hepatitis, or liver cirrhosis, suggestive of alcoholism, and individuals with a history of diabetes mellitus were not included.

Pancreatic tissue samples from the head, body, and tail regions were collected at necropsy, fixed in 10\% formaldehyde, and routinely processed. Each specimen was embedded in paraffin, and $6 \mu \mathrm{m}$ sections were prepared for staining with hematoxylin-eosin (HE) and picrosirius stains. A pathologist, unaware of the group allocation of the cases, performed morphologic and morphometric studies. Using a video camera coupled to a light microscope, 20 PI were measured per section. The images displayed on the video monitor were integrated with a cursor that could be moved across a graphic measuring table that was connected to an interactive image analyzing system that provided linear measurements in $\mu \mathrm{m}$ and areas in $\mu \mathrm{m}^{2}$. Measurements of PI and respective lodging areas (thin layer of conective tissue attach to pancreatic exocrine tissue that delimite PI) were obtained in the head, body, and tail regions of the pancreas.

The PI density, expressed as PI/ $/ \mathrm{mm}^{2}$, was calculated as a ratio of the PI number divided by the area of parenchyma evaluated in 20 microscope fields measuring $4.05 \mathrm{~mm}^{2}$. Pearson's coefficient was used to verify the correlation between PI area and density. In the morphologic analysis, the following parameters were considered: hemorrhages, fibrous, and inflammatory infiltrate, as well as changes in PI cells characterized by increased affinity for nuclei staining and/or enlarged size. The parameter's intensity was semi-quantitatively evaluated as absent, discrete, moderate, or accentuated. A single section from the head, body, and tail regions of the pancreas was examined in each patient. Normally distributed results were evaluated using the Student's $t$ test or variance analysis (ANOVA). Other results were analyzed using the Mann-Whitney and KruskalWallis tests. The chi-square test was used to compare frequencies. In all cases, the differences were considered significant when the probability of rejection of the null hypothesis was less than $5 \%(\mathrm{p}<$ 0.05).

\section{RESULTS}

There were no statistical differences, respectively, among the Megas, CHF, and Control groups in relation to age $(52.3 \pm 17.7$ vs. $57.3 \pm 18.7$ years $)$, predominance of male gender (64.6 vs. $75.5 \%$ ), and white color (77.1 vs. $59.2 \%$ ). There were no statistical differences among the groups in relation to the BMI: Megas $(18.56 \pm 5.09 \mathrm{~kg} /$ $\left.\mathrm{m}^{2}\right)$, CHF $\left(20.93 \pm 6.00 \mathrm{~kg} / \mathrm{m}^{2}\right)$, and Control $\left(19.02 \pm 2.25 \mathrm{~kg} / \mathrm{m}^{2}\right)$. Table 1 shows the areas of PI and respective lodging areas, as well as PI densities, corresponding to the 3 pancreatic segments in Chagas patients and controls. The averages for the Chagas groups were greater, although the differences were not statistically significant. Table 2 shows the comparison between Chagas patients pertaining to the Megas or CHF and Control groups. In the head and body regions, the largest PI areas were in the CHF group, followed by Megas and Control groups.

In the tail region, the greatest PI area was in the Megas group, followed by Control and CHF groups. In the head and body regions, the greatest PI area was in the Megas group, followed by $\mathrm{CHF}$ and Control groups. In the tail region, the sequence observed was Megas, Control, and CHF. In all these comparisons, there was no statistical difference. The PI density in the head region was greater in CHF cases, followed by Megas and Control cases, 


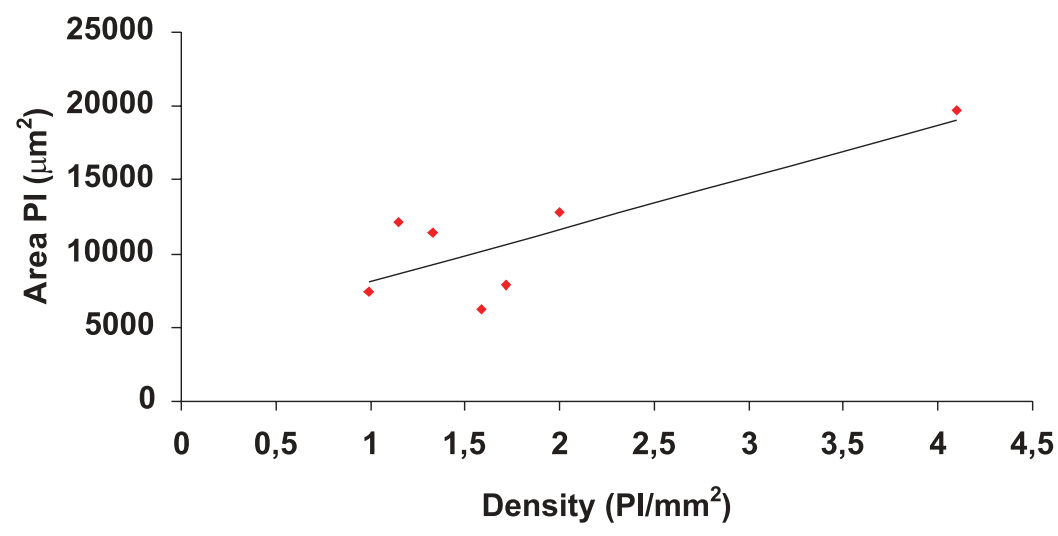

$\mathrm{r}=+0.73 ; \mathrm{t}=2.66 ; \mathrm{p}<0.05$

Figure 1 - Correlation between area and density of pancreatic islets (PI) in the tail of the pancreas in patients with chronic Chagas' disease with megaesophagus and/or megacolon (Megas form).

Table 1 - Comparison of pancreatic islet measurements in patients with chronic Chagas' disease and normal controls.

\begin{tabular}{llcc}
\hline Pancreas & Pancreatic islets (PI) & $\begin{array}{c}\text { Normal controls }(\mathrm{n}=8) \\
(\mathrm{X} \pm \mathrm{SD})\end{array}$ & $\begin{array}{c}\text { Chagas patients }(\mathrm{n}=17) \\
(\mathrm{X} \pm \mathrm{SD})\end{array}$ \\
\hline Head & Area $\left(\mu \mathrm{m}^{2}\right)$ & $7647.5 \pm 2853.2$ & $7975.4 \pm 2192.7$ \\
& Lodging area $\left(\mu \mathrm{m}^{2}\right)$ & $10994.2 \pm 2831.2$ & $11903.3 \pm 3252.0$ \\
& Density $\left(\mathrm{PI} / \mathrm{mm}^{2}\right)$ & $0.7 \pm 0.4$ & $0.8 \pm 0.5$ \\
\hline Body & Area $\left(\mu \mathrm{m}^{2}\right)$ & $7608.6 \pm 2406.5$ & $8766.4 \pm 2304.4$ \\
& Lodging area $\left(\mu \mathrm{m}^{2}\right)$ & $10538.9 \pm 3082.2$ & $12415.4 \pm 3686.1$ \\
& Density $\left(\mathrm{PI} / \mathrm{mm}^{2}\right)$ & $0.7 \pm 0.4$ & $0.8 \pm 0.5$ \\
\hline Tail & Area $\left(\mu \mathrm{m}^{2}\right)$ & $9481.8 \pm 3242.4$ & $10027.7 \pm 3329.3$ \\
& Lodging area $\left(\mu \mathrm{m}^{2}\right)$ & $13179.6 \pm 4149.5$ & $13985.8 \pm 4202.5$ \\
& Density $\left(\mathrm{PI} / \mathrm{mm}^{2}\right)$ & $1.2 \pm 0.7$ & $1.4 \pm 0.9$ \\
\hline Total & & $\mathrm{n}=24$ & $\mathrm{n}=51$ \\
& Area $\left(\mu \mathrm{m}^{2}\right)$ & $8246.0 \pm 2870.0$ & $8923.2 \pm 2741.0$ \\
& Lodging area $\left(\mu \mathrm{m}^{2}\right)$ & $11570.9 \pm 3458.0$ & $14295.6 \pm 10970.7$ \\
& Density $\left(\mathrm{PI} / \mathrm{mm}^{2}\right)$ & $0.7 \pm 0.6$ & $1.0 \pm 0.5$ \\
\hline
\end{tabular}

$\mathrm{P}>0.05$ differing from the body and tail regions, where the PI density was significantly greater in Megas cases, followed by Control and CHF cases. There was a positive and significant correlation $(\mathrm{r}$ $=+0.73$ ) between the PI area and density in the Megas group, especially in the tail of the pancreas (Fig. 1).

Inflammatory infiltrate, absent in all control individuals, was observed as rare isolated foci in 5 sections from Chagas patients, with discrete intensification in 4 of them. Fibrosis of moderate or accentuated intensity was found in 3 control and 11 Chagas cases. There were hemorrhages in 3 sections from control and 4 from Chagas cases. Nuclear changes were found in $12 \mathrm{sec}-$ tions from control cases and 30 sections from Chagas cases. Concerning these parameters, no significant difference was observed between groups. Leukocytic infiltrate and discrete or moderate fibrosis were observed in intrapancreatic nerve ganglions of 2 Chagas individuals. No nests of $T$. cruzi were observed in the pancreas sections examined.

\section{DISCUSSION}

The results show that the PI lodging area, the area, and density of PI

Table 2 - Comparison of pancreatic islets measurements in normal controls and patients with chronic Chagas' disease with megaesophagus and/or megacolon (Megas) or congestive heart failure (CHF).

\begin{tabular}{|c|c|c|c|c|}
\hline \multirow[t]{2}{*}{ Pancreas } & \multirow[t]{2}{*}{ Pancreatic islets (PI) } & \multirow[t]{2}{*}{ Normal controls $(n=8)$} & \multicolumn{2}{|c|}{ Chagas patients $(n=17)$} \\
\hline & & & Megas $(n=8)$ & $\mathrm{CHF}(\mathrm{n}=9)$ \\
\hline \multirow[t]{3}{*}{ Head } & Area $\left(\mu \mathrm{m}^{2}\right)$ & $7647.5 \pm 2853.2$ & $7752.1 \pm 2086.1$ & $8173.9 \pm 2390.3$ \\
\hline & Lodging area $\left(\mu \mathrm{m}^{2}\right)$ & $10994.2 \pm 2831.2$ & $12283.6 \pm 3604.0$ & $11565.2 \pm 3084.4$ \\
\hline & Density $\left(\mathrm{PI} / \mathrm{mm}^{2}\right)$ & $0.7 \pm 0.4$ & $0.8 \pm 0.3$ & $0.8 \pm 0.7$ \\
\hline \multirow[t]{3}{*}{ Body } & Area $\left(\mu \mathrm{m}^{2}\right)$ & $7608.6 \pm 2406.5$ & $8554.2 \pm 2823.2$ & $8.955,0 \pm 1.887,3$ \\
\hline & Lodging area $\left(\mu \mathrm{m}^{2}\right)$ & $10538.9 \pm 3082.2$ & $12696.0 \pm 5036.9$ & $12.166,0 \pm 2.197,0$ \\
\hline & Density $\left(\mathrm{PI} / \mathrm{mm}^{2}\right)$ & $0.7 \pm 0.4$ & $1.1 \pm 0.5$ & $0.6 \pm 0.3$ \\
\hline \multirow[t]{3}{*}{ Tail } & Area $\left(\mu \mathrm{m}^{2}\right)$ & $9481.8 \pm 3242.4$ & $10649.3 \pm 4408.8$ & $9475.1 \pm 2104.9$ \\
\hline & Lodging area $\left(\mu \mathrm{m}^{2}\right)$ & $13179.6 \pm 4149.5$ & $15046.1 \pm 5756.7$ & $13043.0 \pm 2.049 .8$ \\
\hline & Density $\left(\mathrm{IP} / \mathrm{mm}^{2}\right)$ & $1.2 \pm 0.7$ & $1.9 \pm 1.0$ & $0.9 \pm 0.6$ \\
\hline \multirow[t]{4}{*}{ Total } & & $\mathrm{n}=24$ & $\mathrm{n}=24$ & $\mathrm{n}=27$ \\
\hline & Area $\left(\mu \mathrm{m}^{2}\right)$ & $8246.0 \pm 2870.0$ & $8985.2 \pm 3350.0$ & $8868.0 \pm 2124.7$ \\
\hline & Lodging area $\left(\mu \mathrm{m}^{2}\right)$ & $11570.9 \pm 3458.0$ & $16587.7 \pm 15633.5$ & $12258.1 \pm 2467.3$ \\
\hline & Density $\left(\mathrm{IP} / \mathrm{mm}^{2}\right)^{*}$ & $0.9 \pm 0.6$ & $1.2 \pm 0.8$ & $0.8 \pm 0.5$ \\
\hline
\end{tabular}

*Anova: "F" = 3.51; $\mathrm{p}=0.034$. Mann-Whitney (Megas versus $\mathrm{CHF})$ : "U" $=6.93 ; \mathrm{p}=0.008$. 
were greater in Chagas patients, especially among those with Megas form, when compared to controls. This result is in accordance to our previous work, in which the PI size in Chagas patients was significantly larger than in normal individuals ${ }^{10}$. In the Megas group, there were cases with the smallest BMI and the greatest PI area and PI density. So we believed that malnourishment did not interfere in PI size. In the literature on the other hand, an increase of the size of PI in experimentally obese animals ${ }^{15}$ and a decreased size of the pancreas in malnourished children ${ }^{16}$ has been described.

The autonomous nervous system (ANS) involvement in the genesis of cardiac and intestinal manifestations in chronic Chagas patients is well established ${ }^{1,17,18}$. In the present work, intrapancreatic ganglionitis was observed in 2 cases from the Chagas group, which is in agreement with the reduction in the number of neurons in intrapancreatic ganglions described in Chagas patients ${ }^{5,6}$. Furthermore, alterations in the secretion of hormones and other peptides have been demonstrated, suggesting a partial denervation of the PI in Chagas individuals. This denervation could result from ganglionitis or regressive changes in the adjacent pancreatic parenchyma, with fibrosis and hypertrophy of the filaments and nerve ganglions. One may postulate that an intrapancreatic structure functioning as a pacemaker could be responsible for the cyclic oscillatory liberation of insulin in normal individuals and that nerve ganglions would perform this function $^{19,20}$.

In accordance with other studies, we found greater PI densities in the tail region, both in Chagas and normal individuals $^{21}$. Nevertheless, some authors have suggested that there is no relationship between the concentrations of PI in the 3 topographical regions of the pancreas and age, gender, body or pancreatic weight ${ }^{6,22}$. We did not find any mention in the literature about the positive and significant correlation observed here between the density and size of PI in the tail region, especially in patients with the Megas form. Although there is a considerable variation in PI size in normal individuals, the PI number may be inversely proportional to the increase in their size. Moreover, regeneration or new formation of PI, represented by endocrine proliferation and differentiation in duct cells, may be found in some diseases.

On the other hand, patients with the Megas form present more intense denervation of intracardiac ganglions than patients with other clinical forms of Chagas' disease or normal individuals ${ }^{12}$. Loss of ganglion cells is also common in the duodenum of patients with the Megas form of Chagas' disease $^{23}$. Alterations in the absorption of carbohydrates may occur as a consequence of parasympathetic denervation of the small intestine ${ }^{24}$. Studies with rats experimentally infected by $T$. cruzi showed that loss of neurons from the myoenteric plexus may cause disequilibrium in the functioning of the remaining neurons and in the production of some neurotransmitters ${ }^{25}$.

It has also been observed that women with the chronic cardiac form of Chagas' disease have diabetes mellitus and disturbances in the regulation of glycemic level at a higher frequency than normal controls, probably due to reduced activity of the parasympathetic system $^{26}$. Other studies have shown increases in pancreatic weight in rats after total vagotomy ${ }^{27}$. These facts are in agreement with experimental studies on cats that underwent ablation or stimulation of the sympathetic or parasympathetic innervation of the pancreas, in which changes in the number of $\alpha$ or $\beta$ PI cells were found, in addition to possible transformations of pancreatic acinus into PI and vice versa ${ }^{28}$. One may infer that the PI of individuals with Chagas' disease could partially lose the modulatory control of their growth due to a possible disconnection of the pancreas from the digestive intramural ANS resulting from ganglion depopulation.

Although some authors consider insulitis to be specific to diabetes mellitus in the absence of diffuse pancreatitis $^{29}$, insulitis may also be found in other diseases ${ }^{30}$. We did not find intense inflammatory infiltrate in the PI of patients with Chagas' disease; however, new formation of fibrous conjunctive tissue was more frequent in these cases, which is in agreement with other studies 9 . The infiltrate in the conjunctive tissue consisted of lymphocytes and plasmocytes, suggesting an inflammatory cause for fibrosis.

Microvascular involvement could also be a factor in the genesis of fibrosis, similar to Chagas myocarditis ${ }^{31}$, a phenomenon that has been described in patients with diabetes of long duration $^{30}$.

On the other hand, since the average age of the two groups together was $58.2 \pm 10.5$ years, it is possible that this alteration could in part be due to the higher age group of the patients studied. Hemorrhages within the PI, generally discrete, were found in around $30 \%$ of patients in both groups. This is a common finding in necropsies of individuals with other diseases ${ }^{32}$.

We did not find in the literature any data about alterations in PI cell nuclei in patients with Chagas disease. Our analysis of nuclear changes provided similar results in Chagas and Control groups, in accordance with the findings in acinus cells described by Vieira ${ }^{9}$. Although no correlation between nuclear volume and functional activity has yet been established, it is relatively common to find nuclei of variable sizes in endocrine glands of normal individu$\mathrm{als}^{30,32}$.

We did not observe parasitism by $T$. cruzi in the sections examined. In the literature, there is only one description of 
an amastigote nest in the pancreas of a patient with chronic Chagas' disease ${ }^{33}$.

In another human case during the acute phase of Chagas' disease, the pancreas presented neither alterations nor parasitism ${ }^{34}$. However, such parasitic nests have been observed in the pancreas of hamsters and mice during experimental studies on acute Chagas' infection ${ }^{35,36}$.

According to the concept of the enteroinsular axis (EIA), the PI should have important connections with the intestinal tube via the nervous, peptidergic, and substrate routes ${ }^{37,38}$. Increases in neuroendocrine system cell count $^{39}$ and gastrin serum levels ${ }^{40-42}$ associated with reduction of pancreatic polypeptide (PP) levels have been reported $^{40,42}$. Gastrin may act as a growth factor, performing direct trophic actions at various sites including the gastrointestinal mucus and the pancreas ${ }^{43-}$ 45. Based on evidence that the PP of oxen doubles the synthesis of DNA in rats, a growth factor role has also been attributed to PP. Pancreatic polypeptide is found in the head region of the pancreas, and it is particularly related to the cells within PI. In the body and tail regions, the PP producing cells are immunocytochemically seen as dispersed elements between the acinus cells ${ }^{43}$.

Coincidentally, it was in the head region of the pancreas where the Megas group presented PI of the smallest dimensions and densities. It is possible that the gastroenteric-pancreatic hormones may also play some role in the changes of PI density and size described here. There are several reports in the literature, experimental ${ }^{34}$ and clinical $^{8,11,22,24,40,46,47}$ of functional alterations of the pancreas in Chagas' disease including glycemia, glucagon, and insulin responses.

These alterations suggest that the "substrate", the third component of the EIA, may have some role in the trophism and development of PI in individuals with chronic Chagas' disease, or that the changes found in the present work may partially explain the altered results in the laboratory tests described.

The possible involvement of the 3 EIA components associated with the ANS dysfunction and the morphologic alterations in the pancreas of chronic Chagas cases could, acting together, explain the morphologic and morphometric changes described here.

These findings also suggest that the growth, development, and possibly the functioning of the PI are modulated by stimuli from diverse origins, including the nervous system and exocrine, endocrine, and paracrine factors. Our data could help in the clinical and surgical handling of patients with Chagas' disease, in addition to better understanding the great prognostic variation among the different anatomical-clinical forms of Chagas' disease.

\section{ACKNOWLEDGMENTS}

This work was supported by research grants from the Fundação de Ensino e Pesquisa de Uberaba (FUNEPU), Fundação de Amparo a Pesquisa do Estado de Minas Gerais (FAPEMIG), and Conselho Nacional de Desenvolvimento Científico e Tecnológico (CNPq).
SALDANHA JC e col. - Avaliação morfológica e morfométrica das ilhotas pancreáticas na fase crônica da doença de Chagas. Rev. Hosp. Clín. Fac. Med. S. Paulo 56(5): 131-138, 2001.
Objetivo: Hiperglicemia e anormalidades em testes de tolerância à glicose, observadas em alguns pacientes chagásicos crônicos, sugerem um possível papel de alterações morfológicas e desnervação de ilhotas pancreáticas (IP).
Nosso objetivo foi descrever a morfologia e a morfometria de ilhotas pancreáticas na doença de Chagas crônica.

Métodos: Estudo morfológico e morfometria computadorizada foram realizados em fragmentos da cabeça, 
corpo e cauda de pâncreas obtidos em necropsias de oito controles normais e dezessete pacientes chagásicos crônicos; oito com a forma digestiva (Megas) e nove com o quadro clínico de insuficiência cardíaca congestiva.

Resultados: O grupo Megas mostrou ilhotas pancreáticas de maior $(\mathrm{p}<$ $0,05)$ área na cauda do pâncreas $\left(10.649,3 \pm 4.408,8 \mu \mathrm{m}^{2}\right)$ do que os controles normais $(9.481,8 \pm 3.242,4$ $\mu \mathrm{m}^{2}$ ) e que o grupo com insuficiência cardíaca congestiva $(9.475,1 \pm 2.104,9$ $\mu \mathrm{m}^{2}$ ); o mesmo ocorrendo com a densidade das ilhotas na cauda do pâncreas (respectivamente, $1,2 \pm 0,7$ vs. 0,9 $\pm 0,6$ vs. $1,9 \pm 1,0 \mathrm{IP} / \mathrm{mm}^{2}$ ). Na cauda do pâncreas dos casos com Megas, houve correlação positiva e significante $(r=+0,73)$ entre a área e a densidade das ilhotas pancreáticas. Discreta fibrose e infiltrados leucocitários foram vistos nas ilhotas e em gânglios pancreáticos dos pacientes chagásicos. Ninhos de Trypanosoma cruzi não foram observados nos cortes examinados. In- divíduos com a forma Megas da doença de Chagas mostraram aumento da área e da densidade das ilhotas na cauda do pâncreas.

Conclusão: As alterações morfológicas e morfométricas observadas são consistentes com alterações funcionais do pâncreas, incluindo distúrbios da glicemia e da insulinemia.

DESCRITORES: Doença de Chagas. Morfometria. Ilhotas pancreáticas. Pâncreas.

\section{REFERENCES}

1. PRATA A - Chagas' disease. Infect Dis Clin North Am 1994;8:6176.

2. PRATA JA, PRATA JR JA, CASTRO CN et al. - Anisocoria na fase crônica da doença de Chagas. Rev Soc Bras Med Trop 1995;28:131-133.

3. PALMERO HA, CAERO TF, IOSA DJ et al. - Increased prevalence of cholelithiasis in chronic Chagas' disease. Medicina 1982;42:4750 .

4. SANTOS VM, CUNHA SFC, TEIXEIRA VPA et al. - Headache in chagasic women. Rev Inst Med Trop São Paulo 1999;41:119122 .
5. ROCHA A, OLIVEIRA LCM, ALVES RS et al. - Despopulação neuronal pancreática em chagásicos crônicos. Rev Soc Bras Med Trop 1998;31:43-49.

6. SANTOS VM, TEIXEIRA VPA, CUNHA DF et al. - Alterações anatomo-patológicas do pâncreas em chagásicas crônicas. Arq Gastroenterol 1999;36:127-132.

7. VIEIRA CB, SOUBIHE NV \& FERRIOLLI FILHO F - Peculiaridade da hipoglicemia insulínica na forma crônica da moléstia de Chagas. II. - Estudo experimental em cães e ratos infetados pelo Trypanosoma cruzi. Rev Inst Med Trop São Paulo 1970;12:179184. 
8. OLIVEIRA LCM, JULIANO Y, NOVO NF et al. - Blood glucose and insulin response to intravenous glucose by patients with chronic Chagas' disease and alcoholism. Braz J Med Biol Res 1993;26:1187-1190

9. VIEIRA CB \& HADLER WA - Estudo da glândula parótida e do pâncreas no megaesôfago. Rev Ass Med Bras 1961;7:89-96.

10. TEIXEIRA VPA, ALMEIDA HO, GOBBI H et al. - Avaliação morfométrica das ilhotas pancreáticas em chagásicos crônicos. Rev Soc Bras Med Trop 1989;22:80.

11. REIS LCF, OLIVEIRA HL \& VIEIRA C - Curvas glicêmicas anormais observadas em pacientes com a forma crônica da moléstia de Chagas. Rev Goiana Med 1960;6:156-165.

12. ALMEIDA HO, TEIXEIRA VPA, ARAÚJO WF et al. - Alterações do sistema nervoso autônomo intracardíaco em chagásicos com e sem "megas". Rev Goiana Med 1983;29:147-156.

13. JAMES WP, FERRO-LUZZI A \& WATERLOW JC - Definition of chronic energy deficiency in adults. Report of a working party of the International Dietary Energy Consultative Group. Eur J Clin Nutr 1988; 42:969-981.

14. CUNHA DF, FROTA RB, ARRUDA MS et al. - Pressure sores among malnourished necropsied adults - preliminary data. Rev Hosp Clin Fac Med S Paulo 2000;55:79-82.

15. EDVELL A \& LINDSTRÖM P - Vagotomy in young obese hyperglycemic mice: effects on syndrome development and islet proliferation. Am J Physiol 1998;274:E1034-E1039.

16. KHAN LA, ALAM AMS, ALI L et al. - Serum and urinary magnesium in young diabetic subjects in Bangladesh. Am J Clin Nutr 1999; 69:70-73.

17. KÖBERLE F - Patogênese dos megas. Rev Goiana Méd 1956; 2:100110.

18. KÖBERLE F \& NADOR E - Etiologia e patogenia do megaesôfago no Brasil. Rev Paul Med 1955;47:89-107.

19. LANG DA, MATTHEWS DR, PETO J et al. - Cyclic oscillations of basal plasma glucose and insulin concentrations in human beings. N Engl J Med 1979; 301:1023-1027.

20. MATTHEWS DR \& CLARK A - Neural control of the endocrine pancreas. Proc Nutr Soc 1987;46:89-95.

21. ROSS MH, REITH EJ \& ROMRELL LJ - Pancreas. In: ROSS MH, REITH EJ, ROMRELL LJ - Histology a text and atlas. 2nd ed. São Paulo: Panamericana; 1993. p. 481-488.

22. WITTINGEN J \& FREY CF - Islet concentration in the head, body, tail and uncinate process of the pancreas. Ann Surg 1974; 179:412414.

23. TANOWITZ HB, KIRCHHOFF LV, SIMON D et al. - Chagas' disease. Clin Microbiol Rev 1992;5:400-419.

24. MENEGHELLI UG \& REIS LCF - Estudos sobre o metabolismo dos hidratos de carbono na moléstia de Chagas. III. A prova de sobrecarga oral de galactose. Rev Ass Med Bras 1967;13:2-10.

25.FERNANDES MIM, ZUCOLOTO S, COLARES EF et al. Morphometric investigations of the colon mucosa in chronic Trypanosoma cruzi infected rats. Virchows Arch B Cell Pathol 1991;60:119-122.
26. SANTOS VM, CUNHA SFC, TEIXEIRA VPA et al. - Freqüência de diabetes mellitus e hiperglicemia em mulheres chagásicas e nãochagásicas. Rev Soc Bras Med Trop 1999;32:489-496.

27. BÜCHLER M, MALFERTHEINER P, GLASBRENNER B et al. Pancreatic trophism after truncal vagotomy in rats. Am J Surg 1987;154:300-304.

28. SERGEYEVA MA - Microscopic changes in the islands of Langerhans produced by sympathetic and parasympathetic stimulation in the cat. Anat Rec 1940; 77:297-317.

29. LACY PE - The islets of Langerhans. In: BLOODWORTH JR, JMB Endocrine pathology. Baltimore: Williams \& Wilkins; 1968, p. 316-329.

30. GEPTS W \& LECOMPT PM - The pancreatic islets in diabetes. Am J Med 1981;70: 105-115.

31. ROSSI MA \& RAMOS SG - Pathogenesis of chronic Chagas' disease. Cardiovasc Pathol 1996;5:197.

32. CRAWFORD JM \& COTRAN RS - The Pancreas. In: COTRAN RS et al. - Robbins pathologic basis of disease. 6th ed. Philadelphia: Saunders; 1999. p. 902-929.

33. BARBOSA JR. AA \& ANDRADE ZA - Identificação do Trypanosoma cruzi nos tecidos extracardíacos de portadores de miocardite crônica chagásica. Rev Soc Bras Med Trop 1984;17:123-126.

34. CROWELL BC - The acute form of American trypanosomiasis: notes on its pathology, with autopsy report and observations on trypanosomiasis cruzi in animals. Am J Trop Med 1923;3:424454.

35. OKUMURA M, FRANÇA LCM \& CORRÊA NETTO A - Comentários sôbre a patogenia da moléstia de Chagas. Especial referência à infecção experimental em camundongos. Rev Hosp Clin Fac Med São Paulo 1963;18:151-164.

36. RAMIREZ LEG - Suscetibilidade do hamster à infecção pelo Trypanosoma cruzi: estudos parasitológicos comparativos com o camundongo. Uberaba, 1995. [Tese - Faculdade de Medicina do Triângulo Mineiro].

37. CREUTZFELDT W - The incretin concept today. Diabetologia 1979;16:75-85.

38. CREUTZFELDT W, EBERT R, NAUCK M et al. - Disturbances of the entero-insular axis. Scand J Gastroenterol 1983; 82:111-119.

39. BARBOSA AJA, TOPPA NH, MELO JR et al. - Alterações quantitativas das células neuroendócrinas no megacólon chagásico. Rev Soc Bras Med Trop 1985; 18:215-221.

40. LONG RG, ALBUQUERQUE RH, PRATA A et al. - Response of plasma pancreatic and gastrointestinal hormones and growth hormone to oral and intravenous glucose and insulin hypoglycaemia in Chagas's disease. Gut 1980;21:772-777.

41. TRONCON LEA, OLIVEIRA RB, MENEGHELLI UG et al. - Fasting and food-stimulated plasma gastrin levels in chronic Chagas' disease. Digestion 1984;29:171-176.

42. MOTT CB, GUARITA DR, SIPAHI AM et al. - Hormônios gastroêntero-pancreáticos em portadores de doença de Chagas crônica. Rev Hosp Clin Fac Med São Paulo 1989;44:63-72. 
43. POLAK JM, BISHOP AE \& BLOOM SR - Hormônios gastrointestinais. In: DANI R, CASTRO LP - Gastroenterologia. 3rd ed. Rio de Janeiro: Guanabara Koogan; 1978. p. 1793-1813.

44. SAAD JR R, RASSLAN S, BIANCO AC et al. - Avaliação histológica e bioquímica do pâncreas exócrino em ratos submetidos a ressecção ou exclusão jejunoileal extensas. Rev Ass Méd Brás 1988;34:123128.

45. WALSH JH - Role of gastrin as a trophic hormone. Digestion 1990;47:11-16.
46. FORTI NA, GIANNINI SD, PAPALÉO NETTO M et al. - Glicemia e níveis plasmáticos de ácidos graxos livres e de potássio em portadores de cardiopatia chagásica e insuficiência cardíaca congestiva, submetidos ao teste de tolerância à insulina. Rev Hosp Clin Fac Méd São Paulo 1973;28:53-65.

47. KIMACHI T, LOMONACO DA \& VERÍSSIMO JMT - Exploração funcional do eixo hipotálamo-adeno-hipófise-córtex adrenal na forma crônica da moléstia de Chagas. Rev Ass Med Brás 1974;20:57-66.

Received for publication on November 29, 2000 